Sugawara no Michizane

and the

Early Heian Court 


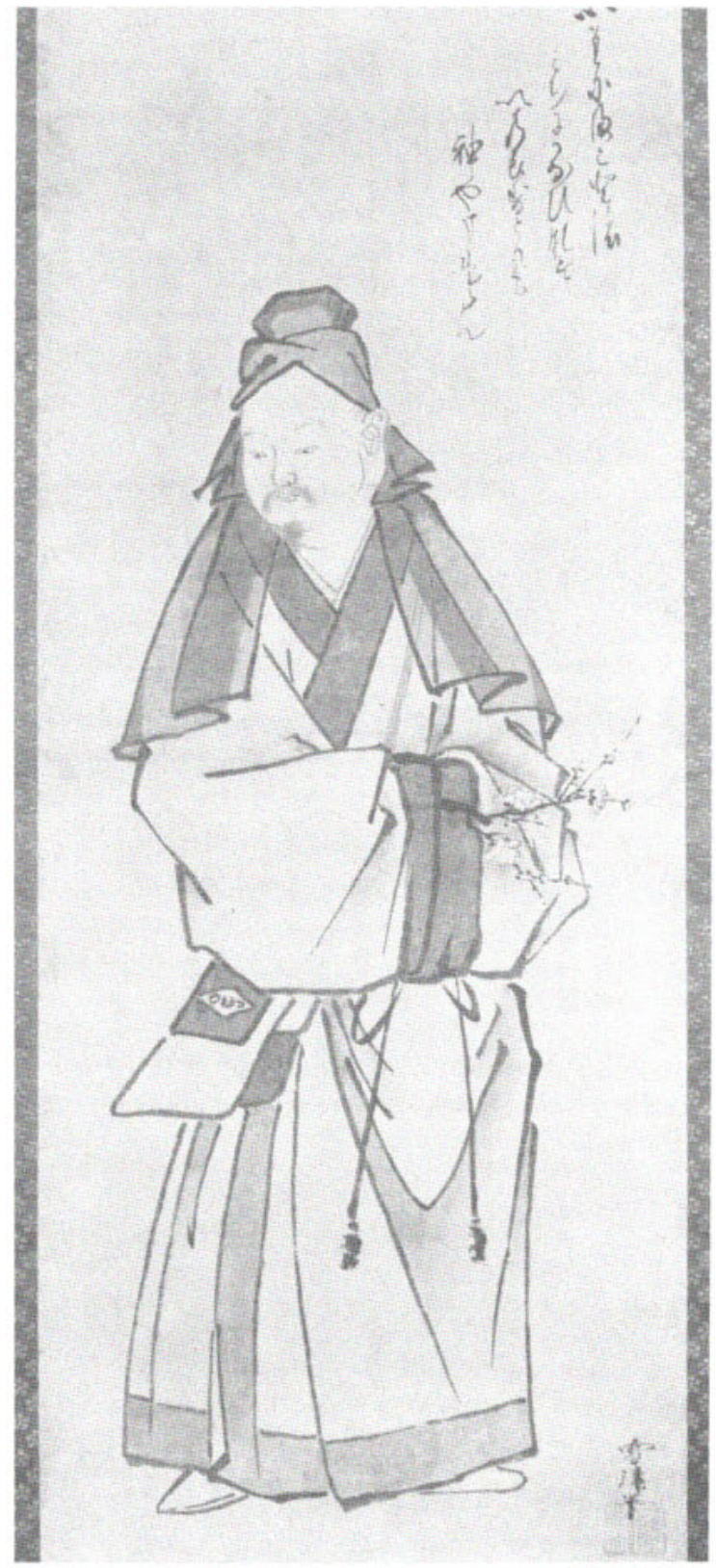

Sugawara no Michizane

Courtesy of the Freer Gallery of Art

Smithsonian Institution, Washington, D.C. (Acc. no 1938.8) 
Sugawara no Michizane and the

Early Heian Court

\section{Robert Borgen}

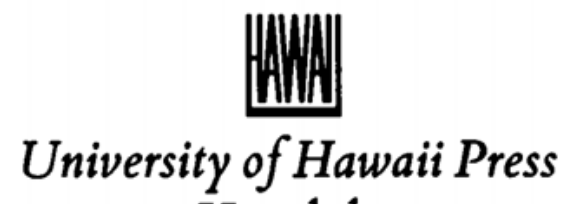

Honolulu 


\section{To my parents \\ Evelyn and Herbert Borgen}

First published by the Council on East Asian Studies,

Harvard University, 1986

Paperback edition

(c) 1994 University of Hawaii Press

All rights reserved

Printed in the United States of A merica

$949596979899 \quad 54321$

Library of Congress Cataloging-in-Publication Data

Borgen, Robert, 1945-

Sugawara no Michizane and the early Heian court / Robert Borgen. -

Pbk. ed.

p. $\mathrm{cm}$.

Includes bibliographical references and index.

ISBN 0-8248-1590-4

1. Sugawara, Michizane, 845-903. 2. Statesmen-Japan-

Biography. I. Title.

[DS856.72.S9B67

952'.01'092-dc20

[B]

93-36993

CIP

University of Hawaii Press books are printed on acid-free paper and meet the guidelines for permanence and durability of the Council on Library Resources 